\title{
ECB Bond Purchases and Quasi-fiscal Activities
}

After the dramatic summit intended to rescue the euro area, the Governing Council of the European Central Bank (ECB) announced several measures in order to ensure an "orderly monetary policy transmission mechanism". On the last days before the ECB changed its course, the impression emerged that the ECB was being driven not only by the markets but also by politics. Many observers argued that, with the bond purchases, national fiscal policies could begin to dominate common monetary policy. The ECB has obviously become less politically independent.

Surprisingly less focus has been put on an aspect that is at least equally important - the slowly vanishing financial independence of the ECB. Who will actually bear the price losses of the purchased private and sovereign bonds if Greece, Portugal or even less risky euro area countries such as Spain prove unable to serve their debt? Ultimately, the owners of the ECB would be asked to pay up, whereby the largest part by far would be imposed on Germany. If the toxic bonds in the balance sheets of the ECB must be written off, the losses to the ECB's reserves and its equity capital could reach into the hundreds of billions of euros. In this case, lower central bank profits would be transferred to the accounts of the euro area governments, and given their public deficits and constant government expenses, higher taxes and duties would inevitably have to be raised. In the extreme case, currently more realistic for the US Fed or the Bank of England than for the ECB, losses could exceed the entire equity capital of the European System of Central Banks. Euro governments would have to remargin capital in order to strengthen the reserves of the ECB or even to prevent the ECB from experiencing negative equity capital.

In order to re-establish the original structure of the central bank balance sheet, governments can simply recapitalise the central bank with newly printed government bonds again and again. One problem emerging in this context is that the "deep long pockets" of the governments are rather deep but also relatively empty in view of the reported public (let alone private) deficit and debt figures. With the bond purchases, the ownership of and the risk associated with these papers is being transferred to the national central banks (NCBs) in the euro area. Should debt waivers or a debt restructuring result, the central banks of the euro area would now be affected directly. Admittedly, the financial system would not be significantly shaken, since the commercial banks would not be holding too many "Greek" bonds. But the potentially huge losses would ultimately be rolled over to the European taxpayer via direct taxation or indirect taxation via inflation. Does the ECB really want to follow in the steps of the Fed?

Up until now, there has been no mechanism available for recapitalising the Eurosystem as a whole. Instead, each national fiscal authority stood behind its own NCB. In view of the current unorthodox monetary policies, this could be interpreted as a fiscal vacuum in the sense of a lack of "fiscal backing" behind the ECB and the Eurosystem. However, combined with the specific and carefully defined accounting principles of repo operations in the euro area, including a conservative imposition of haircuts and the vast reserve liabilities of the euro area national central banks, it is precisely this vacuum that has thus far prevented the ominous tango of euro area governments with the ECB. Until two weeks ago, the ECB was largely unengaged in the outright purchase of bonds except for the covered bond purchasing programme.

The ECB has decided to purchase bonds in a sterilised fashion in order to forcefully confront the accusation that it is monetising government debt. But how airtight is the envis- 
aged sterilisation of bond purchases as a protection against inflationary consequences? And does it target the main problem of unlimited bond purchases, the fact that confidence in the political and financial independence of the ECB is on the line?

In the implementation of its new "minimum price guarantees" for sovereign bonds, the ECB does not know exactly how many bonds it will have to buy in order to stabilise the prices of the jeopardised bonds sustainably. To be on the safe side, it will buy more than necessary, which will tend to expand the money supply to an unnecessary extent. In addition, the sterilisation measures have been merely promised; except for the tender of a time deposit used to gauge how it will work, they are in fact non-mandatory. Conflicts of interest between the national central banks within the ECB are bound to occur. This is especially true given that the consolidation processes in countries such as Greece or Portugal will need more than half a decade to succeed - if they are to succeed at all. What is more, a central bank in a country plagued by severe fiscal problems will consistently claim - with the support of European commercial banks and traders - that the markets' movements are "dysfunctional" and that the market for domestic bonds has dried up and is in dire need of support.

Portuguese bonds would become even less attractive. This would clearly counteract the spirit of the most recent rescue package for the euro area. Apart from that, even a successful sterilisation would not smooth things over. If actually used for sterilisation purposes, the issuance of ECB debt certificates would contribute to a huge transfer of sovereign risk to ECB balance sheets. Offering time deposits to banks would not prevent this transfer. The ECB would be acting as a fiscal agent, taxing other euro area creditors through higher bond rates in order to support a government in an emergency financial situation.

The problem inherent in both sterilisation approaches is that they merely deal with a reorganisation of the structure of the liability side of the ECB's balance sheet. Neither approach is well-suited to either diminish the bloated ECB balance sheet or to remove the (potentially) toxic covered or sovereign bonds from this balance sheet. In addition, the intake of potentially toxic assets in the central bank balance sheet both as collateral and through outright purchases artificially keeps the asset prices up. A credible strategy of sterilisation and a monetary policy strategy fighting the consequences of the financial crisis in general should, thus, deal primarily with the asset side of the ECB balance sheet.

It was no surprise that the ECB's bond purchases were only initially effective. Only a short time later, the euro plummeted to a four-year low. Obviously, investors do not trust the "newly designed" euro area any more. From the outset, it appeared doubtful that the instantly lower bond spreads truly signalled a gradual increase in confidence in bond markets. It is much more likely that the activities of the ECB tend to bias bond prices of peripheral euro area countries and fuel scepticism as to whether and for how long the lower risk premiums can be sustained. If central banks intervene against the market, i.e. against the fundamentally not improbable insolvencies of Greece and Portugal, it is unlikely to end well. Imagine the politico-economic scenario and the intense political pressures on the ECB at that future point in time when the bonds must - as promised - be resold to the markets and the country-specific risk premiums will skyrocket again quasi-automatically! It appears rather clear that the ECB will have to capitulate again, which in turn implies that we will have definitely seen the long-term "exit from the exit" from ultra-loose monetary policies in the euro area as well. The ECB's actions today should be undertaken with precisely this scenario in mind. An "anything goes" monetary policy must be avoided by all means. A central bank's credibility is one asset that cannot be replaced! 